\title{
In vitro first order dry matter disappearance kinetics of chemically and physically treated cottonseed hulls
}

A Faramarzi Garmroodi, M Danesh Mesgaran, A R Vakili, A R Heravi Moussavi, A Tahmasbi, H Jahani-Azizabadi Department of Animal Science, Excellence Center for Animal Science, Ferdowsi University of Mashhad, Mashhad, Islamic Republic of Iran

Email: ali_faramarzi_g@yahoo.com

Introduction Limited supplies and or high costs of conventional roughages and concentrates dictate that alternate sources of feeds should be used in ruminant rations (Brown et al., 1976). Cottonseed hulls $(\mathrm{CH})$ are a by-product of cotton processing, containing a large proportion of neutral detergent fibre (NDF) and associated lignin, and have been considered as a useful non-forage fibre source in ruminant rations (Hall and Akinyode, 2000). However, low dry matter (DM) digestibility of $\mathrm{CH}$ is an inhibitory factor to include this feedstuff in the high performance dairy cow diets (Brown et al, 1976). Results of previous in vitro studies have revealed that sodium hydroxide treatment of fibrous feedstuffs can improve DM or NDF digestibility of them. The objective of this study was to determine the effect of chemical, using sodium hydroxide, or physical treatment, using microwave irradiation, on in vitro DM disappearance kinetics of $\mathrm{CH}$.

Material and methods For chemical treatment, $\mathrm{CH}$ were treated with $\mathrm{NaOH}$ as $20 \mathrm{~g} / \mathrm{kg} \mathrm{DM}$ [a $20 \%$ solution of $\mathrm{NaOH}$ was sprayed on $\mathrm{CH}$ and kept for $0.5 \mathrm{~h}(\mathrm{CH} 2 \mathrm{~S} 0.5)$ or $48 \mathrm{~h}(\mathrm{CH} 2 \mathrm{~S} 48)]$ or $40 \mathrm{~g} / \mathrm{kg} \mathrm{DM}$ [a $40 \%$ solution of $\mathrm{NaOH}$ was sprayed on $\mathrm{CH}$ and kept for $0.5 \mathrm{~h}(\mathrm{CH} 4 \mathrm{~S} 0.5)$ or $48 \mathrm{~h}(\mathrm{CH} 4 \mathrm{~S} 48)$ at room temperature]. Physical processing was done using microwave irradiation (900 W) for 4, 6 and $8 \mathrm{~min}(\mathrm{CHm} 4, \mathrm{CHm} 6, \mathrm{CHm} 8$, respectively). Samples were incubated in a medium prepared as described by Arroquy et al. (2005). Forty-five $\mathrm{ml}$ of medium was supplied into a $100 \mathrm{ml}$ bottle containing 0.45 g DM of each sample (Four replicates per each sample were run). Then, each bottle was inoculated under carbon dioxide with $5 \mathrm{ml}$ of mixed rumen microbes. Rumen fluid was obtained from three sheep $(49.5 \pm 2.5 \mathrm{~kg}$ body weight $)$ fitted by rumen fistulae, before the morning feeding, and immediately strained through four layers of cheesecloth. The animals fed 1 $\mathrm{kg} / \mathrm{d}$ of DM lucerne hay and $0.3 \mathrm{~kg} / \mathrm{d} \mathrm{DM}$ concentrate $(165 \mathrm{~g} \mathrm{CP} / \mathrm{kg} \mathrm{DM})$. The bottles were incubated for 24, 48, 72 and 96 $\mathrm{h}$ at $38.6^{\circ} \mathrm{C}$. After each time of incubation, bottle contents were filtered through a $42 \mu \mathrm{m}$ filter, and DM of unfiltered medium was determined. Non-linear first order model was used to estimate the digestion kinetic parameters of DM. The model was $\mathrm{D}_{(\mathrm{t})}=D_{(i)} \cdot e^{-k d . t}+I$; where, $\mathrm{D}_{(\mathrm{t})}$ is residual $\mathrm{DM}$ at any time, $D_{(i)}$ is potentially degradable fraction, $k_{d}$ is fractional rate constant of digestion $\left(\mathrm{h}^{-1}\right)$ and $I$ is indigestible fraction.

Results Non-linear first order parameters of in vitro DM disappearance of the samples are presented in Table 1. Physical or chemical treatment had no significant effect on DM disappearance parameters of $\mathrm{CH}$.

Table1 Non-linear first order parameters of in vitro DM disappearance of non treated or chemically and physically treated cottonseed hulls

\begin{tabular}{lllllllllll}
\hline & Treatments & & & & & & & \\
Parameters & CH & CH2S0.5 & CH2S48 & CH4S0.5 & CH4S48 & CHm4 & CHm6 & CHm8 & s.e.m & P \\
\hline $\mathrm{D}_{\mathrm{i}}$ & 0.310 & 0.310 & 0.260 & 0.340 & 0.350 & 0.300 & 0.26 & 0.290 & 0.088 & $\mathrm{P}>0.05$ \\
$\mathrm{~K}_{\mathrm{d}}$ & 0.007 & 0.016 & 0.011 & 0.006 & 0.009 & 0.008 & 0.011 & 0.010 & 0.005 & $\mathrm{P}>0.05$ \\
$\mathrm{I}$ & 0.140 & 0.140 & 0.190 & 0.110 & 0.110 & 0.150 & 0.190 & 0.160 & 0.091 & $\mathrm{P}>0.05$ \\
$\mathrm{R}^{2}$ & 0.97 & 0.93 & 0.98 & 0.96 & 0.96 & 0.98 & 0.97 & 0.97 & \\
\hline
\end{tabular}

Conclusions Results of the present study indicate that non-linear first order parameters of in vitro DM disappearance of $\mathrm{CH}$ were not influenced by the chemical or physical processing. Present results did not confirm previous findings used $\mathrm{NaOH}$ to enhance the ruminal degradability of NDF sources (Ololade et al., 1975). It was previously indicated that DM digestion of forages might be enhanced by $\mathrm{NaOH}$ treatment (Canale et al., 1985). Sadeghi and Shawrang (2008) showed microwave irradiation caused a decrease in degradation potential of barley grain starch. However, present results indicate that it is not beneficial to use microwave irradiation for enhancing the DM digestibility of $\mathrm{CH}$.

Acknowledgements The authors gratefully acknowledge funding from Excellence Centre for Animal Science, Ferdowsi University of Mashhad.

\section{References}

Arroquy, J. I., Cochran, R. C., Nagaraja, T. G., Titgemeyer, E. C., and Johnson, D. E. 2005. Animal Feed Science and Technology. 120, 93-106.

Brown, W. H., Whiting, F. M., Daboll, B. S., Turner, R. J., and Schuh, J. D. 1976. Journal of Dairy Science. 60, 6.

Canale, C. J., Abrams, S. M., Muller, L. D., Kjelgaard, W. L., Anderson, P. M., and Harpster, H. W. 1988. Journal of Dairy Science. 71, 2166-2174.

Hale, W. H., Lambeth, C., Theurer, B., and Ray, D. E. 1969. Journal of Animal Science. 29, 773-776.

Hall, M. B. and Akinyode, A. M. 2000. Proceedings of $11^{\text {th }}$ Annual Florida Ruminant Nutrition Symposium. 179-186

Ololade, B. G. and Mowat, D. N. 1975. Journal of Animal Science. 40, 351-357.

Sadeghi, A. A. and Shawrang, P. 2008. Animal Feed Science and Technology. 141, 184-194. 